\title{
Correction to: Educational Leaders Building Relationships and Respecting and Affirming Indigenous Identity
}

Joseph Martin, Jon Reyhner, Richard Manning, Josephine Steeves, and Larry Steeves

\section{Correction to:}

Chapter "Educational Leaders Building Relationships and Respecting and Affirming Indigenous Identity" in: J. C. Veenis et al. (eds.), Multiculturalism and Multilingualism at the Crossroads of School Leadership, Policy Implications of Research in Education 11, https://doi.org/10.1007/978-3-030-54750-9_6

The original version of this book was inadvertently published with incorrect affiliation and e-mail id for chapter author "J. Steeves" has been updated as in below:

From

J. Steeves

Government of Canada, Oakville, Canada

e-mail: josephine.steeves@ canada.ca

To

J. Steeves

University of Saskatchewan, Saskatoon, Canada

e-mail: josie.steeves@usask.ca

The correction chapter and book have been updated with the changes. 